\title{
DAS の最適軌道制御に関する一研究*1 A Study about Optimal Orbital Control of DAS
}

\author{
付 天 爽*2 · 今 度 史 昭*3
}

Tianshunag Fu and Fumiaki IMADO

Key Words : Dive and Ascent Satellite, Orbital Control, Minimum Fuel Consumption, Steepest Ascent Method

\begin{abstract}
DAS (Dive and Ascent Satellite) is a kind of satellite that can approach very close to the earth, which was designed by NAL (National Aerospace Laboratory of Japan) in later 1970's. Now we paid attention to the function of the satellite that can descend and ascend, and proposed to use it for getting detailed information of the area which is suffered from a natural disaster. In this paper orbital control of DAS with minimum fuel consumption is discussed, where the earth is treated as an ellipsoid of revolution, the atmosphere drag and the second zonal coefficient is considered. The optimal orbital control problems are treated as nonlinear two point boundary problems, and solved by the steepest ascent method. The derivation of equations and results are shown in detail.
\end{abstract}

\section{1. は じめに}

近年多くの自然災害が発生しており，迅速な災害状況の 把握と対策が重要視されている.地球観測衛星を用いて被 災情報を収集する場合，従来の観測衛星では軌道高度およ び軌道傾斜角の制限により，必要な観測精度を迅速に得る ことが困難である．弚こでわれわれはDAS を用いて被災 地上空の近距離で観測することを提案する.

DAS は 1970 年代後半 NAL が電離圏を観測するために 提案したものであるが1,2)，ここではDAS の降下および再 上昇できる能力を利用し，DAS を地球上空の近いところへ 降下させて被災地の観測を行わせる．弚のために，DAS の 軌道変換を燃料消費最小の問題として定式化し，最適制御 と最適経路を求める研究を進めてきた ${ }^{3,4)}$.

本稿において, まず地球中心赤道面基準慣性座標系, 軌 道面基準座標系, 軌道面座標系およびこれらの座標系間の 座標変換について説明する。慣性座標系において空気抵抗 および帯状調和関数 2 次の項を考慮した DAS の運動方程式 を示す. 次に最適軌道制御を求めるための数学的手法, 最 急上昇法およびそのアルゴリズムを説明する . 次に燃料消 費を最小とするDAS の最適軌道変換制御の計算結果を示 し，考察する．最後に本稿をまとめる．

1970 年代 NASA は上昇および降下できる衛星 Explorer C , D , E を運用した .一方 70 年代後半, NAL は DAS の 予備的な研究を行った。しかし, 弚れらの衛星は地球表面

*1 (C) 2007 日本航空宇宙学会

平成 17 年 7 月 26 日, The 15th Workshop on JAXA Astrodynamics and Flight Mechanics, 平成 17 年 8 月 9 日, SICE Annual Conference 2005 in Okayama において発表. 平成 18 年 4 月 3 日原稿受理

*2 信州大学工学部総合工学系研究科システム開発工学専攻

$* 3$ 信州大学工学部
の物体を観測するために用いられるものではなかった .な お，产の後 DAS の研究は行われていない (米国て情報衛 星に利用されているとも言われているが, 公表されたもの は皆無である) .われわれの提案が実現すれば, 既存の観測 センサーを用いて十分な観測精度が得られ，必要な情報を 迅速に収集することができる .

\section{2. 座標系および衛星の運動方程式}

この章では本研究で使用する座標系および衛星の運動方 程式について詳しく説明する．

2.1 座標系 本研究では地球を回転楕円体で近似した． 地球モデルのパラメーターは次の通りである5).

赤道方向半径 : $R_{\mathrm{e}}=6378.137 \mathrm{~km}$

極方向半径 : $R_{\mathrm{p}}=6356.752 \mathrm{~km}$

扁平率 : $\alpha=1 / 298.257222$

自転の角速度 : $\omega_{\mathrm{e}}=7.292115 \times 10^{-5} \mathrm{rad} / \mathrm{s}$

地心重力定数 : $\mu_{\mathrm{e}}=398600.4 \mathrm{~km}^{3} / \mathrm{s}^{2}$

絶対空間に固定されている座標系を絶対座標系と呼び, 絶 対座標系に対して等速直線運動をしている座標系を慣性座 標系と呼ぶ . 太陽は銀河系の中心周りを回転しており，地 球は太陽の周りを公転しているが, 地球近傍の運動を取り 扱うとき地球中心に原点があり，地球とともに自転しない 座標系を慣性座標系とみなす．以下第 1 图に示す座標系に ついて説明する。

A. 地球中心赤道面基準慣性座標系 $\Phi$

座標系の原点 $O$ は地球の中心にあり, $X-Y$ 平面を赤道 面にとり， $Z$ 軸は地球の自転軸に一致させ , 北極の方向を 正とする $. X, Y$ 軸は地球とともに回転せず空間に固定し， $X$ 軸の正の方向を春分点方向とする．

B. 軌道面基準座標系 $\Phi_{R}$

地球中心に座標系の原点をとり， $Z_{R}$ 軸を軌道面べクト 


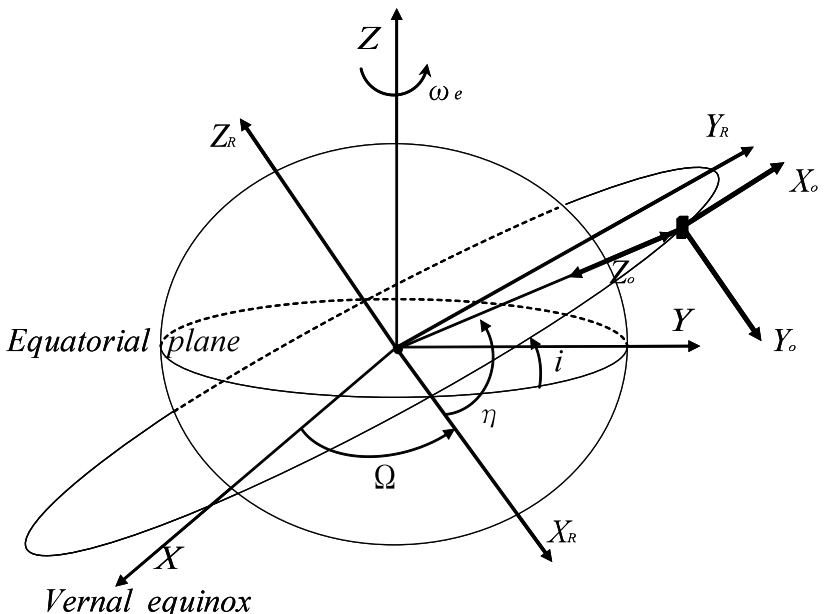

第1図 座標系と記号

ル方向に， $X_{R}$ 軸を昇交点方向にとり， $Y_{R}$ 軸はこれらと 右手系をなすようにとる .

C. 軌道座標系 $\Phi_{o}$

座標系の原点を衛星の重心に固定し, 衛星より地心方向 に向けて $Z_{o}$ 軸, 軌道面ベクトル負方向に $Y_{o}$ 軸をとり， $X_{o}$ 軸はこれらと右手系をなすようにとる ( $X_{O}$ 軸は軌道面内 にあり，円軌道においては衛星の進行方向と一致する) . 軌 道座標系は衛星の運動とともに回転するので, 慣性座標系 ではない(6)。

2.2 座標変換 本節では座標系間の座標変換を示す．

春分点方向と昇交点方向とのなす角 $\Omega$ を昇交点赤経, 昇 交点方向と $Z_{o}$ 軸の負方向とのなす角 $\eta$ を緯度引数, 赤道 面と軌道面のなす角 $i$ を軌道傾斜角と呼ぶ . $\Phi$ を $Z$ 軸周 りに $\Omega$, 次に $X$ 軸周りに $i$ 回転すると $\Phi_{R}$ になる. $\Phi_{R}$ を $Z_{R}$ 軸周りに $\eta, Y_{R}$ 軸周りに $-\pi / 2$, 最後に $Z_{R}$ 軸周 りに $\pi / 2$ 回転する.このようにしてできた座標系の原点を 衛星の重心に平行移動したものが $\Phi_{o}$ になる.$\Phi$ から $\Phi_{o}$ への座標変換行列を $\boldsymbol{A}$ とすると

$\boldsymbol{A}=\left[\begin{array}{ccc}-S_{\eta} C_{\Omega}-C_{\eta} C_{i} S_{\Omega} & -S_{\eta} S_{\Omega}+C_{\eta} C_{i} C_{\Omega} & C_{\eta} S_{i} \\ -S_{i} S_{\Omega} & S_{i} C_{\Omega} & -C_{i} \\ -C_{\eta} C_{\Omega}+S_{\eta} C_{i} S_{\Omega} & -C_{\eta} S_{\Omega}-S_{\eta} C_{i} C_{\Omega} & -S_{\eta} S_{i}\end{array}\right]$

ここで $S$ と $C$ は “Sin” と “Cos” の略である . また $\Phi_{o}$ か ら $\Phi$ への座標変換行列を $B$ とすると

$$
\begin{aligned}
\boldsymbol{B} & =\boldsymbol{A}^{-1} \\
& =\left[\begin{array}{ccc}
-S_{\eta} C_{\Omega}-C_{\eta} C_{i} S_{\Omega} & -S_{i} S_{\Omega} & -C_{\eta} C_{\Omega}+S_{\eta} C_{i} S_{\Omega} \\
-S_{\eta} S_{\Omega}+C_{\eta} C_{i} C_{\Omega} & S_{i} C_{\Omega} & -C_{\eta} S_{\Omega}-S_{\eta} C_{i} C_{\Omega} \\
C_{\eta} S_{i} & -C_{i} & -S_{\eta} S_{i}
\end{array}\right]
\end{aligned}
$$

2.3 衛星の運動方程式 地球を回転楕円体で近似した 場合の重力ポテンシャル $U$ は次の式で表される7) (縞状 · 扇状調和関数係数は以下に述べる $J_{2}$ に比べて十分小さい ので回転楕円体で近似できる) .

$$
U=\frac{\mu_{\mathrm{e}}}{r}\left[1-\sum_{n=2}^{\infty} J_{n}\left(\frac{R_{\mathrm{e}}}{r}\right)^{n} P_{n}\left(\sin \varphi_{\mathrm{e}}\right)\right]
$$

ここで $\varphi_{\mathrm{e}}$ は地心緯度, $r$ は衛星から地球中心までの距離で ある・また， $P_{n}$ はルジャンドル (Legendre) の陪関数， $J_{n}$ は帯状調和関数係数である. $J_{n}$ の大きさを見ると,$n=2$ の場合 $J_{2}=1082.628 \times 10^{-6}$ に比べて,$n=3$ 以下が極 端に小さい.したがって， $n=2$ までとった次の式で，十 分な精度の近似が得られる。

$$
U=\frac{\mu_{\mathrm{e}}}{r}\left[1-J_{2}\left(\frac{R_{\mathrm{e}}}{r}\right)^{2} \frac{3 \sin ^{2} \varphi_{\mathrm{e}}-1}{2}\right]
$$

上式を慣性座標で表すと

$$
U=\frac{\mu_{\mathrm{e}}}{r}\left\{1-J_{2}\left(\frac{R_{\mathrm{e}}}{r}\right)^{2}\left[\frac{3}{2}\left(\frac{z}{r}\right)^{2}-\frac{1}{2}\right]\right\}
$$

推力と外乱力が作用している衛星の運動方程式は次のよう になる．

$$
\ddot{\boldsymbol{x}}=\frac{\partial U}{\partial \boldsymbol{x}}+(\boldsymbol{F}+\boldsymbol{D}) / m
$$

ここで $\boldsymbol{x}$ は慣性座標ベクトル $(x, y, z)^{\mathrm{T}}, \partial U / \partial \boldsymbol{x}$ は地球 の引力による衛星の加速度ベクトルである . また $\boldsymbol{F}$ は制 御外力ベクトル, $\boldsymbol{D}$ は外乱力ベクトル， $m$ は衛星の質量 である . 式 (2.6) を慣性座標成分で表すと次式になる.

$$
\left\{\begin{array}{l}
\ddot{x}=-\frac{\mu_{\mathrm{e}}}{r^{3}}\left\{1-\frac{3 R_{\mathrm{e}}^{2}}{2 r^{2}} J_{2}\left(5 \frac{z^{2}}{r^{2}}-1\right)\right\} x+\left(f_{x}+d_{x}\right) / m \\
\ddot{y}=-\frac{\mu_{\mathrm{e}}}{r^{3}}\left\{1-\frac{3 R_{\mathrm{e}}^{2}}{2 r^{2}} J_{2}\left(5 \frac{z^{2}}{r^{2}}-1\right)\right\} y+\left(f_{y}+d_{y}\right) / m \\
\ddot{z}=-\frac{\mu_{\mathrm{e}}}{r^{3}}\left\{1-\frac{3 R_{\mathrm{e}}^{2}}{2 r^{2}} J_{2}\left(5 \frac{z^{2}}{r^{2}}-3\right)\right\} z+\left(f_{z}+d_{z}\right) / m
\end{array}\right.
$$

ここで $f_{x}, f_{y}, f_{z}$ は制御外力成分， $d_{x}, d_{y}, d_{z}$ は外乱力 成分である.

本研究では低軌道 (軌道高度 $500 \mathrm{~km}$ 以下) の衛星を取り 扱っており，空気の抵抗力が他の外乱力より極端に大きい ため, ここでは空気の抵抗力のみを外乱力として用いる8, 9). 兴の 3 成分を次式に示す。

$$
\left\{\begin{aligned}
d_{x} & =\frac{1}{2} \rho(h) S C_{\mathrm{D}} V V_{x} \\
d_{y} & =\frac{1}{2} \rho(h) S C_{\mathrm{D}} V V_{y} \\
d_{z} & =\frac{1}{2} \rho(h) S C_{\mathrm{D}} V V_{z}
\end{aligned}\right.
$$

ここで $S$ は衛星の基準面積， $V$ は衛星の絶対速度， $V_{x}, V_{y}$, $V_{z}$ は速度ベクトル $\boldsymbol{V}$ の成分， $C_{\mathrm{D}}$ は空気抗力係数， $\rho(h)$ は空気の密度である . 高度 $80 \sim 1000 \mathrm{~km}$ の空気の密度を第 2 図に示す。

$\left(f_{x o}, f_{y o}, f_{z o}\right)^{\mathrm{T}}$ を衛星に固定された $X_{o}, Y_{o}, Z_{o}$ 方向の 


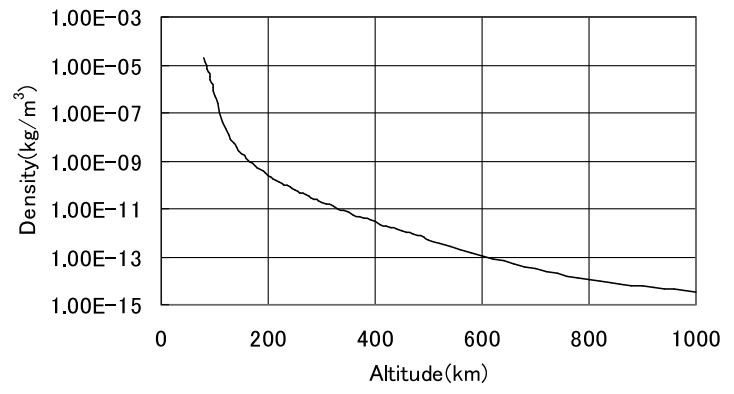

第 2 図 高度に対する空気の密度

スラスタの推力とすると, 2.2 節に示した座標変換によって 制御外力成分は

$$
\begin{aligned}
\left(\begin{array}{c}
f_{x} \\
f_{y} \\
f_{z}
\end{array}\right)= & {\left[\begin{array}{ccc}
-S_{\eta} C_{\Omega}-C_{\eta} C_{i} S_{\Omega} & -S_{i} S_{\Omega} & -C_{\eta} C_{\Omega}+S_{\eta} C_{i} S_{\Omega} \\
-S_{\eta} S_{\Omega}+C_{\eta} C_{i} C_{\Omega} & S_{i} C_{\Omega} & -C_{\eta} S_{\Omega}-S_{\eta} C_{i} C_{\Omega} \\
C_{\eta} S_{i} & -C_{i} & -S_{\eta} S_{i}
\end{array}\right] } \\
& \times\left(\begin{array}{c}
f_{x o} \\
f_{y o} \\
f_{z o}
\end{array}\right)
\end{aligned}
$$

となる.

2.4 軌道要素 衛星の単位質量角運動量 $\boldsymbol{h}=\boldsymbol{x} \times \boldsymbol{V}$ と すると

$$
\left\{\begin{array}{l}
h_{x}=y V_{z}-z V_{y} \\
h_{y}=z V_{x}-x V_{z} \\
h_{z}=x V_{y}-y V_{x}
\end{array}\right.
$$

ここで $h_{x}, h_{y}, h_{z}$ は角運動量の成分である. 衛星の軌道 要素は $\Omega, i$ の他に近地点引数 $\omega$, 真近点離角 $\theta$, 離心率 $e$ および長半径 $a$ がある. また緯度引数 $\eta=\omega+\theta$, 半長 弦 $p=a\left(1-e^{2}\right)$ も用いられる. これらの慣性座標におけ る表示はケプラーの法則によって次のように与えられる .

$$
\begin{aligned}
& a=\left(\frac{2}{r}-\frac{V^{2}}{\mu_{\mathrm{e}}}\right)^{-1} \\
& p=\frac{h^{2}}{\mu_{\mathrm{e}}} \\
& \Omega=\tan ^{-1}\left(\frac{h_{x}}{-h_{y}}\right) \\
& i=\tan ^{-1}\left[\frac{\left(h_{x}^{2}+h_{y}^{2}\right)^{\frac{1}{2}}}{h_{z}}\right] \\
& \eta=\tan ^{-1}\left(\frac{z h}{y h_{x}-x h_{y}}\right)
\end{aligned}
$$

\section{3. 最適化の手法}

DAS の最適軌道制御は，初期条件および終端条件が与え られた 2 点境界值問題である .このような問題の解法は変分 を用いない数理計画法, 動的計画法 (Dynamic Programming)，と変分を用いる変分法 (Calculus of Variation) お よび最大原理 (Maximum Principle) がある.最大原理の
本質も変分原理であり，これを用いた数值解法も数多く考 案されている.最大原理の諸法を大別すると，間接法 (Indirect Method) および直接法 (Direct Method) となる. 間接法は最大原理を適用した上で, 境界条件を修正するな どして間接的に最適制御べクトルを求める.直接法は制御 ベクトルを直接修正して最大原理および境界条件を満たす 最適制御べクトルを求めようとする手法である.直接法はま た最急上昇法 (最急降下法とも呼引゙），共役勾配法，二ュー トン法等がある、最急上昇法は勾配法の中で最も簡明な手 法であるが, 最適点の近傍における収束が悪いという欠点 がある . 共役勾配法はお互いに共役な探索方向を用い, 計 算が簡単で収束も良い.ニュートン法は，2 階の導関数を 用いるので計算が複雑となり, 収束の保証もない。

最急上昇法と共役勾配法を拡張してできたアルゴリズ ムは Steepest Ascent Method Algorithm (SAMA) ${ }^{10)}$ と Sequential Conjugate Gradient Restoration Algorithm (SCGRA) である .SCGRA は未知パラメーターを含む最 適化問題に有力であるが , 一般的に非常に計算時間がかか るので, ここでは SAMAを用いた。

最急上昇法は解くべき問題を以下のように定式化する .

$$
\begin{aligned}
& \dot{\boldsymbol{x}}=\boldsymbol{f}[\boldsymbol{x}(t), \boldsymbol{u}(t), t] \quad \text { (システム方程式) } \\
& \boldsymbol{x}\left(t_{0}\right)=\boldsymbol{x}_{0} \quad \text { (初期条件) } \\
& \boldsymbol{\Psi}\left[\boldsymbol{x}\left(t_{\mathrm{f}}\right), t_{\mathrm{f}}\right]=0 \quad \text { (終端拘束条件) }
\end{aligned}
$$

のもとに評価関数

$$
J=\phi\left[\boldsymbol{x}\left(t_{\mathrm{f}}\right), t_{\mathrm{f}}\right]
$$

を最大 (または最小) にする制御べクトル $\boldsymbol{u}(t)$ を $t_{0} \leq t \leq$ $t_{\mathrm{f}}$ の間で求める.ここで終端時間 $t_{\mathrm{f}}$ は停止条件

$$
\Omega\left[\boldsymbol{x}\left(t_{\mathrm{f}}\right), t_{\mathrm{f}}\right]=0
$$

より定まるものである .ここで

$$
\begin{array}{rr}
\boldsymbol{x}(t)=\left[x_{1}(t), \cdots, x_{n}(t)\right]^{\mathrm{T}} & (n \text { 次元状態ベクトル }) \\
\boldsymbol{u}(t)=\left[u_{1}(t), \cdots, u_{l}(t)\right]^{\mathrm{T}} & (l \text { 次元制御ベクトル })
\end{array}
$$

である . 最適解を求める SAMA の手順は次のようになる .

(1) 適当な制御べクトルの履歴 $\boldsymbol{u}(t)$ を与える (公称制御 と呼引゙）.

(2) 初期条件と $\boldsymbol{u}(t)$ を用いて停止条件 (3.5) 式が満足さ れるまでシステム方程式を積分する. $\boldsymbol{x}(t)$ と $\boldsymbol{\Psi}\left[\boldsymbol{x}\left(t_{\mathrm{f}}\right), t_{\mathrm{f}}\right]$ を記録し，次の偏微分の時間履歴を計算する。

$$
\boldsymbol{F}(t)=\frac{\partial \boldsymbol{f}}{\partial \boldsymbol{x}}, \quad \boldsymbol{G}(t)=\frac{\partial \boldsymbol{f}}{\partial \boldsymbol{u}}
$$

(3) ステップ $(2)$ で得た $\boldsymbol{x}\left(t_{\mathrm{f}}\right)$ を用いて影響関数の境界条 件式 (3.9) を計算し，これを用いて (3.10) を逆時間で積分 し $\boldsymbol{\lambda}_{\phi}, \boldsymbol{\lambda}_{\Psi}$ および $\boldsymbol{\lambda}_{\Omega}$ を決定する . 次に影響関数式 (3.11) 
を計算する .

$$
\begin{aligned}
& \left\{\begin{array}{l}
\boldsymbol{\lambda}_{\phi}\left(t_{\mathrm{f}}\right)=\left(\frac{\partial \phi}{\partial \boldsymbol{x}}\right)_{t_{\mathrm{f}}} \\
\boldsymbol{\lambda}_{\Omega}\left(t_{\mathrm{f}}\right)=\left(\frac{\partial \Omega}{\partial \boldsymbol{x}}\right)_{t_{\mathrm{f}}} \\
\boldsymbol{\lambda}_{\Psi}\left(t_{\mathrm{f}}\right)=\left(\frac{\partial \boldsymbol{\Psi}}{\partial \boldsymbol{x}}\right)_{t_{\mathrm{f}}}
\end{array}\right. \\
& \left\{\begin{array}{l}
\dot{\boldsymbol{\lambda}}_{\phi}=-\boldsymbol{\lambda}_{\phi} \frac{\partial \boldsymbol{f}}{\partial \boldsymbol{x}} \\
\dot{\boldsymbol{\lambda}}_{\Omega}=-\boldsymbol{\lambda}_{\Omega} \frac{\partial \boldsymbol{f}}{\partial \boldsymbol{x}} \\
\dot{\boldsymbol{\lambda}}_{\Psi}=-\boldsymbol{\lambda}_{\Psi} \frac{\partial \boldsymbol{f}}{\partial \boldsymbol{x}}
\end{array}\right. \\
& \left\{\begin{array}{l}
\boldsymbol{\lambda}_{\phi \Omega}=\boldsymbol{\lambda}_{\phi}-\frac{\dot{\phi}\left(t_{\mathrm{f}}\right)}{\dot{\Omega}\left(t_{\mathrm{f}}\right)} \boldsymbol{\lambda}_{\Omega} \\
\boldsymbol{\lambda}_{\Psi \Omega}=\boldsymbol{\lambda}_{\Psi}-\frac{\dot{\boldsymbol{\Psi}}\left(t_{\mathrm{f}}\right)}{\dot{\Omega}\left(t_{\mathrm{f}}\right)} \boldsymbol{\lambda}_{\Omega}
\end{array}\right.
\end{aligned}
$$

(4) ステップ 3 と同時に次の積分量を計算する .

$$
\left\{\begin{array}{l}
\boldsymbol{I}_{\Psi \Psi}=\int_{t_{0}}^{t_{\mathrm{f}}} \boldsymbol{\lambda}_{\Psi \Omega}^{\mathrm{T}} \boldsymbol{G} \boldsymbol{W}^{-1} \boldsymbol{G}^{\mathrm{T}} \boldsymbol{\lambda}_{\Psi \Omega} \mathrm{d} t \\
\boldsymbol{I}_{\Psi \phi}=\int_{t_{0}}^{t_{\mathrm{f}}} \boldsymbol{\lambda}_{\Psi \Omega}^{\mathrm{T}} \boldsymbol{G} \boldsymbol{W}^{-1} \boldsymbol{G}^{\mathrm{T}} \boldsymbol{\lambda}_{\phi \Omega} \mathrm{d} t \\
I_{\phi \phi}=\int_{t_{0}}^{t_{\mathrm{f}}} \boldsymbol{\lambda}_{\phi \Omega}^{\mathrm{T}} \boldsymbol{G} \boldsymbol{W}^{-1} \boldsymbol{G}^{\mathrm{T}} \boldsymbol{\lambda}_{\phi \Omega} \mathrm{d} t
\end{array}\right.
$$

(5) 終端拘束式 (3.3) に近づくように $\delta \boldsymbol{\Psi}$ の值を選ぶ . 例 えば

$$
\delta \boldsymbol{\Psi}=-\varepsilon \boldsymbol{\Psi}\left[\boldsymbol{x}\left(t_{\mathrm{f}}\right), t_{\mathrm{f}}\right] \quad 0<\varepsilon \leq 1
$$

上式を満たし，かつ $J$ を増加させる $\delta \boldsymbol{u}(t)$ は次のように なる。

$$
\delta \boldsymbol{u}(t)=\left(\frac{1}{2 \mu}\right) \boldsymbol{W}^{-1} \boldsymbol{G}^{\mathrm{T}}\left(\boldsymbol{\lambda}_{\phi \Omega}-\boldsymbol{\lambda}_{\Psi \Omega} \boldsymbol{\nu}\right)
$$

ここで

$$
\left\{\begin{array}{c}
2 \mu=\left[\frac{I_{\phi \phi}-\boldsymbol{I}_{\Psi \phi}^{\mathrm{T}} \boldsymbol{I}_{\Psi \Psi}^{-1} \boldsymbol{I}_{\Psi \phi}}{(d p)^{2}-\delta \boldsymbol{\Psi}^{\mathrm{T}} \boldsymbol{I}_{\Psi \Psi}^{-1} \delta \boldsymbol{\Psi}}\right]^{\frac{1}{2}} \\
\boldsymbol{\nu}=-2 \mu \boldsymbol{I}_{\Psi \Psi}^{-1} \delta \boldsymbol{\Psi}+\boldsymbol{I}_{\Psi \Psi}^{-1} \boldsymbol{I}_{\Psi \phi}
\end{array}\right.
$$

ここで $d p$ と $(l \times l)$ 行列の重み関数 $\boldsymbol{W}(t)$ は次式を満足 するように選ぶ。

$$
(d p)^{2}=\int_{t_{0}}^{t_{\mathrm{f}}} \delta \boldsymbol{u}^{\mathrm{T}}(t) \boldsymbol{W}(t) \delta \boldsymbol{u}(t) \mathrm{d} t
$$

(6) 改良された $\boldsymbol{u}(t)$ を用いて $J$ の増加が十分に小さく なるまでステップ(1) から (5) までを繰り返す.

$$
\boldsymbol{u}(t)=\boldsymbol{u}(t)_{\text {old }}+\delta \boldsymbol{u}(t)
$$

\section{4. 燃料消費を最小とする軌道変換制御}

燃料は衛星寿命の最も重要な要素である . 衛星は制御用 の燃料がなくなると衛星の姿勢が保たれなくなると同時に， 摂動によって元の軌道から離れてしまい，衛星本来の機能 が失われる.従って最小の燃料消費で衛星を制御すること は重要なテーマである .

DAS を用いて被災地を観測する場合，詳細な情報を収集 するために DAS が被災地の上空の最も近い距離において 観測することが望ましい，弚のためには DAS の軌道の最 低点付近が被災地の上空になるように制御しなければなら ない. 乥こでこのような軌道変換を最小の燃料消費で行う 最適制御問題として解く. 衛星の軌道制御と共に姿勢も制 御しなければならないが, 姿勢制御に必要な燃料は極僅か であるので,ここでは無視している。

4.1 最適軌道高度变換制御 本節では軌道傾斜角 $97.049^{\circ}, 55^{\circ}$ および $0^{\circ}$ の軌道面上にある衛星を本来の高 度 $400 \mathrm{~km}$ の円軌道から降下させ , $100 \mathrm{~km}$ の高度に達した 後上昇させ，最終的に元の高度 $400 \mathrm{~km}$ の円軌道に戻す .こ の一連の制御を最少の燃料で実行する計算の方法と結果を 示す. 計算に当たり，次の仮定を設けた：

制御の開始点は軌道面上任意の点にすべきであるが，こ こでは便宜上衛星の軌道が春分点 $(6778.137,0,0)$ を通 過するものとし, 衛星がこの点を通過する時点を軌道制御 開始点とする . 今後の計算の開始点はすべてこの点とする . 衛星の高度は地球の中心から衛星までの距離 $r$ から，㚇の $r$ と同一線上において, 地球の中心から地表までの距離を 差し引いたものである. 空気抗力係数は自由分子流におい ての抗力係数 2 とした ${ }^{2)}$. これは壁における分子の反射を 完全鏡面反射と仮定したと考えてよい，なお，高度 $100 \mathrm{~km}$ から $135 \mathrm{~km}$ までの間は遷移流域になる .この間の抗力係 数は 2 以下になるが, 研究の初期段階で抗力係数を煩雑に するのは得策ではないと考えて 2 に固定した . また , 軌道 の傾斜角が $0^{\circ}$ のとき式 $(2.13)$ と (2.15) の分母が 0 にな り， $\Omega$ と $\eta$ が定義できなくなるので, $0^{\circ}$ に近似する傾斜 角 $0.02^{\circ}$ を用いた. 更に, 軌道の傾斜角が $55^{\circ}$ と $97.049^{\circ}$ を用いたのは GPS 衛星の軌道の傾斜角と太陽同期軌道の 傾斜角を考慮したためである.NAL が考案した DAS の形 状は球款付円筒であり，大きさは直径 $1413 \mathrm{~mm}$, 平行部長 さ $937 \mathrm{~mm}$ としている.また質量は $250 \mathrm{~kg}$ で, 姿勢制御 はスピン安定制御であった .ここではより軌道制御を精密 に実現させるため, 衛星の姿勢はガスジェットによる 3 軸 制御を考えている．また軌道制御は機体の 3 軸の正・負方 向に設置された推力 $500 \mathrm{~N}$ のスラスタによって行うと仮定 した . 本研究で用いた DAS の機体と軌道の初期パラメー ターを第 1 表に示す。

燃料消費を最小とする軌道高度変換制御の評価関数を

$$
J=\phi\left[\boldsymbol{x}\left(t_{\mathrm{f}}\right), t_{\mathrm{f}}\right]=m_{t_{\mathrm{f}}}
$$

とし，Jを最大になるように評価する。つまり軌道制御終 了後の残留質量が最大であれば燃料消費が最小になる．以 
第 1 表 衛星の機体と軌道の初期パラメーター

\begin{tabular}{lc}
\hline 機体パラメーター & $350 \mathrm{~kg}$ \\
初期質量 & $1 \times 1 \times 1\left(\mathrm{~m}^{3}\right)$ \\
形状 & $313 \mathrm{~s}$ \\
スラスタの推力 & $( \pm 500) \times( \pm 500) \times( \pm 500)(\mathrm{N})$ \\
$I_{\mathrm{sp}}$ & 0 \\
\hline 初期軌道パラメーター & \\
離心率 & $6778.137 \mathrm{~km}$ \\
軌道半径 & $97.049^{\circ} / 55^{\circ} / 0^{\circ}$ \\
傾斜角 & $7.66856 \mathrm{~km} / \mathrm{s}$ \\
接線速度 & $5553.63 \mathrm{~s}$ \\
周期 $T_{0}$ & \\
\hline \multicolumn{2}{c}{}
\end{tabular}

下に具体的な定式を示す．

システム方程式 :

$$
\left\{\begin{array}{l}
f_{1}=V_{x} \\
f_{2}=V_{y} \\
f_{3}=V_{z} \\
f_{4}=-\frac{\mu_{\mathrm{e}}}{r^{3}}\left\{1-\frac{3 R_{\mathrm{e}}^{2}}{2 r^{2}} J_{2}\left(5 \frac{z^{2}}{r^{2}}-1\right)\right\} x+\left(f_{x}+d_{x}\right) / m \\
f_{5}=-\frac{\mu_{\mathrm{e}}}{r^{3}}\left\{1-\frac{3 R_{\mathrm{e}}^{2}}{2 r^{2}} J_{2}\left(5 \frac{z^{2}}{r^{2}}-1\right)\right\} y+\left(f_{y}+d_{y}\right) / m \\
f_{6}=-\frac{\mu_{\mathrm{e}}}{r^{3}}\left\{1-\frac{3 R_{\mathrm{e}}^{2}}{2 r^{2}} J_{2}\left(5 \frac{z^{2}}{r^{2}}-3\right)\right\} z+\left(f_{z}+d_{z}\right) / m \\
f_{7}=\dot{m}=-k\left(\left|f_{x o}\right|+\left|f_{y o}\right|+\left|f_{z o}\right|\right)
\end{array}\right.
$$

ここで $k=1 /\left(g_{0} I_{\mathrm{sp}}\right), g_{0}=9.80665 \mathrm{~m} / \mathrm{s}^{2}, I_{\mathrm{sp}}$ は燃料の 比推力である .

終端拘束条件 :

$$
\left\{\begin{array}{l}
\Psi_{1}=r-r_{\mathrm{f}}=0 \\
\Psi_{2}=a-a_{\mathrm{f}}=0 \\
\Psi_{3}=p-p_{\mathrm{f}}=0
\end{array}\right.
$$

停止条件：

$$
\Omega=t-t_{\mathrm{f}}=0
$$

状態変数：

$$
\boldsymbol{x}=\left(x, y, z, V_{x}, V_{y}, V_{z}, m\right)^{\mathrm{T}}
$$

制御変数 :

$$
\boldsymbol{u}=\left(f_{x o}, f_{y o}, f_{z o}\right)^{\mathrm{T}}
$$

実際の計算には基準化を施す. 更に拘束条件をペナルティ 関数として評価関数に導入する.すなわち

$$
\begin{aligned}
\bar{J} & =\phi\left[\boldsymbol{x}\left(t_{\mathrm{f}}\right), t_{\mathrm{f}}\right] \\
& =\left[m-\frac{1}{2} k_{r}\left(r-r_{\mathrm{f}}\right)^{2}-\frac{1}{2} k_{a}\left(a-a_{\mathrm{f}}\right)^{2}-\frac{1}{2} k_{p}\left(p-p_{\mathrm{f}}\right)^{2}\right]_{t_{\mathrm{f}}}
\end{aligned}
$$

ここで $k_{r}, k_{a}, k_{p}$ はペナルティ係数である.このようにす

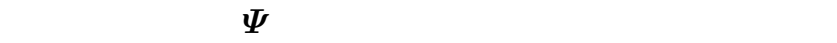
単になる $. k_{r}, k_{a}, k_{p}$ の値を非常に大きくとることによっ て, 終端時間 $t_{\mathrm{f}}$ における $r, a, p$ の值は $r_{\mathrm{f}}, a_{\mathrm{f}}, p_{\mathrm{f}}$ に近づ く.すなわち終端拘束条件式を導入しなくても, 状態変数 の終端時間における值が拘束できる $. r-r_{\mathrm{f}}, a-a_{\mathrm{f}}, p-p_{\mathrm{f}}$ は 0 に限りなく近づけば，

$$
\bar{J}=J=\phi\left[\boldsymbol{x}\left(t_{\mathrm{f}}\right), t_{\mathrm{f}}\right]=m_{t_{\mathrm{f}}}
$$

になる．

計算には降下制御の部分と上昇制御の部分に分けて最適 計算を行った . 降下制御のときに

$$
\left\{\begin{array}{l}
r_{\mathrm{f}}=6478.137 \mathrm{~km} \\
a_{\mathrm{f}}=6628.137 \mathrm{~km} \\
p_{\mathrm{f}}=6624.747 \mathrm{~km}
\end{array}\right.
$$

とした .これらは地球中心に対して遠地点高度 $400 \mathrm{~km}$ $\left(r_{a}=6778.137 \mathrm{~km}\right)$, 近地点高度 $100 \mathrm{~km}\left(r_{p}=6478.137\right.$ $\mathrm{km}$ ) の楕円軌道のパラメーターである (軌道周期 $T_{1}=$ $5370.30 \mathrm{~s})$. 上昇制御のときに初期值は降下制御の終端值 として

$$
\left\{\begin{array}{l}
r_{\mathrm{f}}=6778.137 \mathrm{~km} \\
a_{\mathrm{f}}=6778.137 \mathrm{~km} \\
p_{\mathrm{f}}=6778.137 \mathrm{~km}
\end{array}\right.
$$

とした . 停止時間は降下制御のときも上昇制御のときも，楕 円軌道の周期 $T_{1}$ の半分

$$
t_{\mathrm{f}}=T_{1} / 2=2685 \mathrm{~s}
$$

とした 、つまり降下制御において，制御により開始から $2685 \mathrm{~s}$ 後, 終端拘束が満足されることによって DAS は高 度 $100 \mathrm{~km}$ 一降下する . 同樣に上昇制御において，制御に より開始から $2685 \mathrm{~s}$ 後, 終端拘束か満足されることによっ て DAS の軌道は高度 $400 \mathrm{~km}$ の円軌道になる. 重み関数 $\boldsymbol{W}(t)$ を単位行列

$$
\boldsymbol{W}=\left[\begin{array}{lll}
1 & 0 & 0 \\
0 & 1 & 0 \\
0 & 0 & 1
\end{array}\right]
$$

とした . 積分計算には 4 次の Runge-Kutta-Gill 法を用い て，積分間隔を $5 \mathrm{~s}$ とした。

傾斜角 $97.049^{\circ}$ の軌道面において, DAS を高度 $400 \mathrm{~km}$ から $100 \mathrm{~km}$ へ降下させる最適な推力パターンの求め方を 例とし，収束判定法を示す。

衛星の軌道高度降下制御はスラスタを軌道面内で軌道速 度を減少する接線方向に噴射することによって実現される ことが周知である.本研究において円軌道では $X_{o}$ 軸の正方 向が衛星速度の方向と一致するため,ここでまず制御計算開 始から $40 \mathrm{~s}$ 間 $f_{x o}$ の値を $-500 \mathrm{~N}$ として与える. 弚の後の 時間では 0 とする $. f_{y o}, f_{z o}$ の值は制御開始から最後まで 0 とする.この公称制御で計算した結果， $r-r_{\mathrm{f}}=87.99 \mathrm{~km}$ ， 


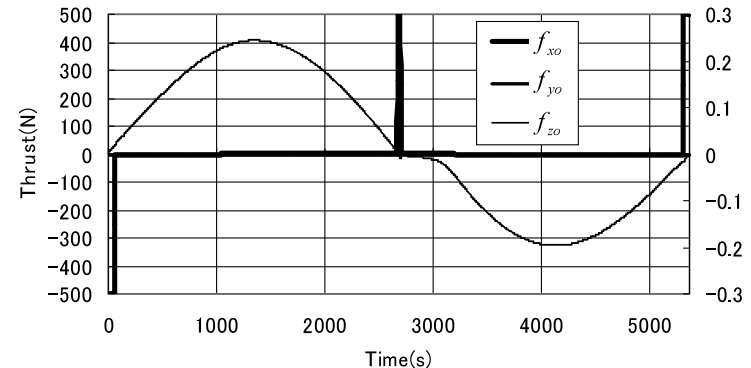

第3図最適制御パターン

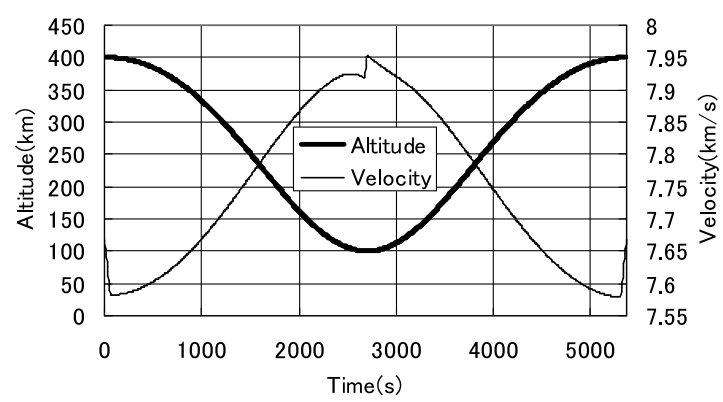

第 4 図 DAS の速度と軌道高度の履歴

$a-a_{\mathrm{f}}=44.048 \mathrm{~km}, p-p_{\mathrm{f}}=45.746 \mathrm{~km}$ となった . この後 $k_{r}, k_{a}, k_{p}$ を調整し, SAMA を用いて収束する まで計算すると， $r-r_{\mathrm{f}}=0 \mathrm{~km}, a-a_{\mathrm{f}}=0.018 \mathrm{~km}$ ， $p-p_{\mathrm{f}}=0.087 \mathrm{~km}, m_{t_{\mathrm{f}}}=337.71 \mathrm{~kg}$ となった . また $45 \mathrm{~s}$ から $1560 \mathrm{~s}$ まで $f_{x o}$ は $-10.052 \mathrm{~N}$ から $-0.021 \mathrm{~N}$ の值に なり, $1565 \mathrm{~s}$ から $2685 \mathrm{~s}$ まで $0.025 \mathrm{~N}$ から $6.051 \mathrm{~N}$ の値 になった . 次に $f_{x o}$ の值を計算開始から $50 \mathrm{~s}$ 間 $-500 \mathrm{~N}$, $2680 \mathrm{~s}$ から $2685 \mathrm{~s}$ まで $500 \mathrm{~N}$ ，他の時間で 0 として与える . $f_{y o}, f_{z o}$ の值は制御開始から最後まで 0 とする .この公称 制御を用いて収束するまで計算すると， $m_{t_{\mathrm{f}}}=338.19 \mathrm{~kg}$ となった . 谷の後, 樣々の公称制御を用いて計算し, 最終 的に $m_{t_{\mathrm{f}}}$ の最大值 $338.263 \mathrm{~kg}$ となる最適制御パターンを 得た .なお, 公称制御を変えるたびに計算が収束するよう に試行錯誤的に $d p$ を変えている.$d p$ は修正量 $\delta \boldsymbol{u}(t)$ にノ ルムを与える．あまり $d p$ を大きくとりすぎると計算が収 束しなくなり, また $d p$ が小さすぎれば修正の能率が悪く なる . 本計算で最適解を得たときの $d p$ は 0.01 であった . 最適計算結果を降下制御と上昇制御を合わせて第 3 ～図 に示す. 最適制御パターン (第 3 図) と速度と軌道高度の 履歴 (第 4 図) を合わせて見ると次のことが分かる .まず 遠地点付近で $X_{o}$ 正方向のスラスタが噴射すること $\left(f_{x o}\right.$ が負になる）によって衛星の速度が減少し, 衛星の高度が 下がる．次に近地点付近で $X_{o}$ 負方向のスラスタか噴射し， 大気の抵抗力を克服して衛星の速度を増加させる . 最後に $X_{o}$ 負方向のスラスタか噴射することによって速度を増加 させ , 衛星を元の $400 \mathrm{~km}$ の円軌道に駐留させる . 計算では $f_{x o}$ の絶対值が最大值とならない場合があるが , 中間值の 推力はスラスタのデューティサイクルを調整して実現でき る .この計算結果では衛星の最低点の高度は $99.886 \mathrm{~km}$ と なっているが, $100 \mathrm{~km}$ との誤差が僅か $0.114 \%$ であり, 計

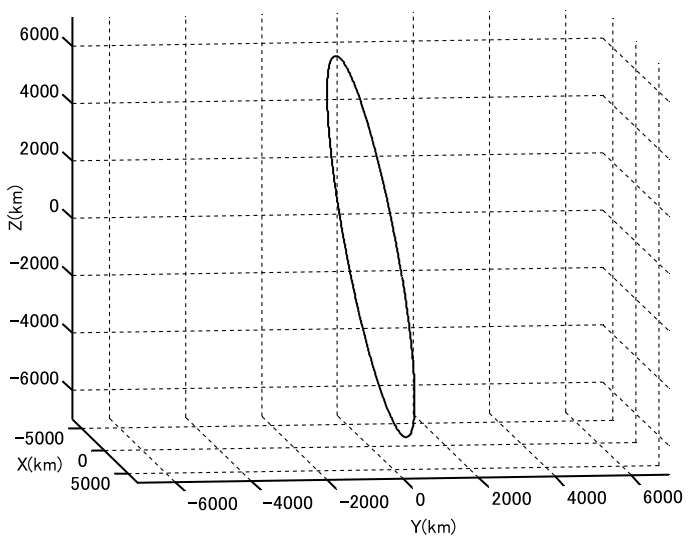

第 5 図 DAS の最適軌道

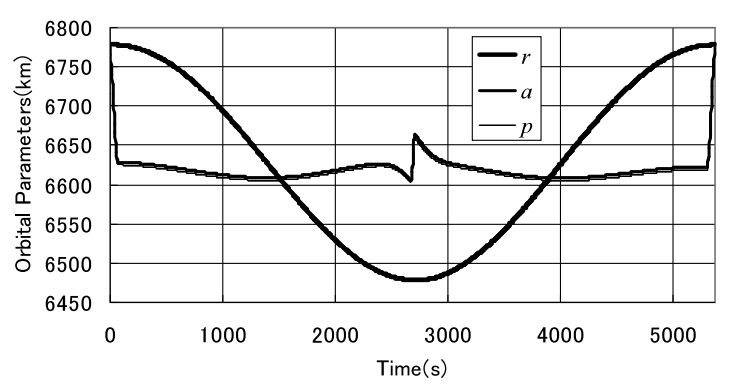

第 6 図 $r, a, p$ の履歴

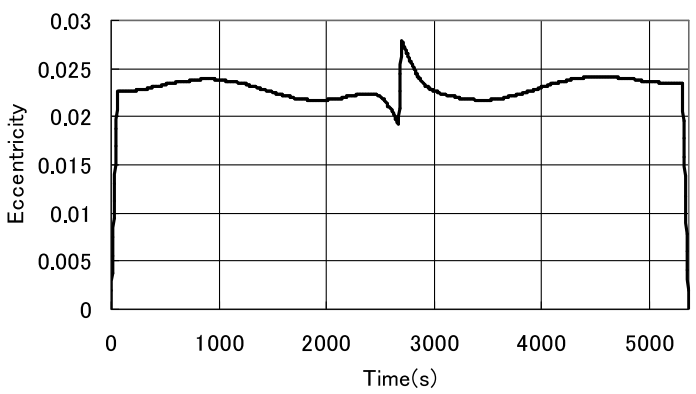

第 7 図 DAS の離心率の履歴

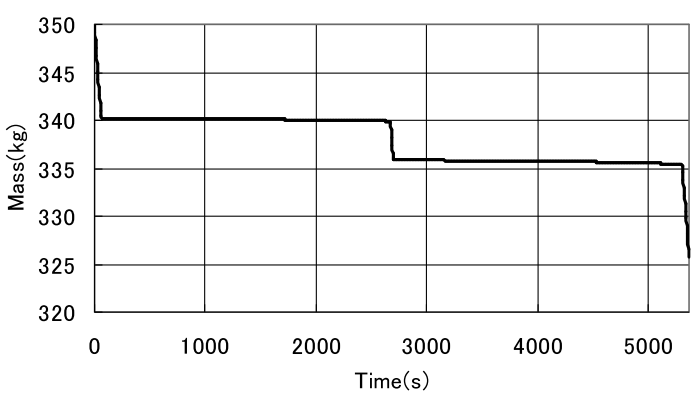

第 8 図 DAS の質量の履歴

算結果は十分実用的な精度と考える.なお， $f_{y o}$ の絶対値 は $0.001 \mathrm{~N}$ 以下であり，実際の衛星の制御では無視してよ い.また $f_{z o}$ の絶対值は $0.244 \mathrm{~N}$ 以下なので, 軌道制御用 のメインエンジンを用いず, 姿勢制御用の小推力のエンジ ンを用いれば必要な推力が得られる.

最適制御による衛星の軌道を第 5 図に示す. 第 6 図にお 
いて $a, p$ の値は降下制御のときに急激に減少し, 近地点付 近で空気抵抗および制御外力の作用によって急激な変化が 見られ，最後に遠地点で制御開始の值と同じになる．衛星 の離心率 (第 7 図) は制御開始のときも制御終了のときも 0 であることが分かる.これは制御の前に衛星が円軌道で飛 行しており，制御後も円軌道で飛行していることを意味す る.衛星の質量 (第 8 図) はスラスタの噴射によって, 遠地 点付近および近地点付近で急激に減少していることが分か る.制御後の衛星の残留質量は $325.694 \mathrm{~kg}$ である.つまり 燃料消費は $24.306 \mathrm{~kg}$ で衛星の初期質量の $6.945 \%$ になる . この衛星を用いて同樣の制御をもう 1 回実行すると，燃料 消費は残留質量の $6.945 \%, 22.618 \mathrm{~kg}$ となる.従って衛星 の初期質量の $50 \%$ か燃料であれば，同樣な制御を 9 回実行 することができる．

軌道傾斜角 $55^{\circ}$ と $0^{\circ}$ の場合の計算結果は軌道経路以外は 傾斜角 $97.049^{\circ}$ の場合と似たようなものであるので, ここ では図を省略する.燃料消費は傾斜角 $55^{\circ}$ の場合 $24.763 \mathrm{~kg}$ ， 傾斜角 $0^{\circ}$ の場合 $24.982 \mathrm{~kg}$ である.これらの燃料消費は傾 斜角 $97.049^{\circ}$ の場合より高いことが分かる. 弚れは赤道上 の点を除いて $r$ が同じであっても，傾斜角 $97.049^{\circ}$ の軌道 面上の点の高度が最も高く, 空気の密度が最も小さいため， 空気の抵抗力が最も少ないからである.また，軌道傾斜角 $0^{\circ}$ の場合, 軌道面上の点の高度が最も低く空気の抵抗力も 最も大きい，よって燃料消費は最大になる．

4.2 ホーマン遷移と空気抵抗を無視した最適制御 前 節の結果と比較するために軌道傾斜角 $97.049^{\circ}$ の軌道面に おいて，ホーマン遷移および空気抵抗を無視した場合の最 適制御の計算を行った . ホーマン遷移の場合は最適計算で はなく, 単なるシミュレーション (積分間隔を $1 \mathrm{~s}$ ) で計算 した。また，空気抵抗を無視した場合の最適制御計算は, 空 気の抵抗力を 0 とした以外は前節の諸条件と同じである． 計算結果を第 9〜12 図に示す.

ホーマン遷移の燃料消費は $23.467 \mathrm{~kg}$ である . これは最 適軌道変換制御の燃料消費 $24.306 \mathrm{~kg}$ より $0.839 \mathrm{~kg}$ 少ない ことが分かる . 燃料損失の原因は 2 つあると考えられる . (1) 最適軌道変換制御の場合, 最低点の高度は $99.886 \mathrm{~km}$ となったため, $100 \mathrm{~km}$ より下がった分空気抵抗が大きくな り，弚れを克服するため余分な燃料が使われた . (2) ホー マン遷移と異なり有限の推力で行う最適軌道変換制御の推 力の方向は，速度の接線方向と完全に一致していないので， 軌道変換に必要な運動量を提供するため, 燃料が多く使わ れた．空気抵抗を無視した場合の最適推力パターン (第 11 图) は, 近地点付近で推力 $f_{x o}$ の值が 0 となっており，ス ラスタの噴射は必要としないことが分かる．また，この場 合の燃料消費は $21.555 \mathrm{~kg}$ となる .これは空気抵抗に費や す燃料は $2.751 \mathrm{~kg}$ であることを意味する .

4.3 軌道面と高度の同時変換 DAS を用いて被災地を 観測するとき, DAS の軌道面付近に被災地か現れなければ 詳細な情報を得ることはできない，光のような場合 DAS の 軌道を被災地に合わせるため, 軌道面の変換が必要になる かもしれない.ここでは軌道傾斜角 $0^{\circ}$ から $2^{\circ}$ への軌道面

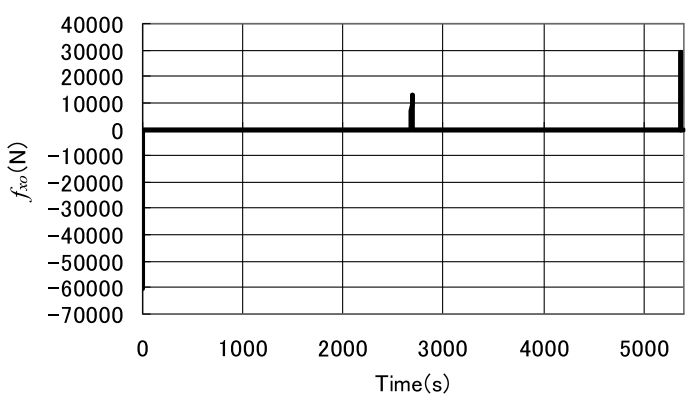

第 9 図 ホーマン遷移の推カパターン

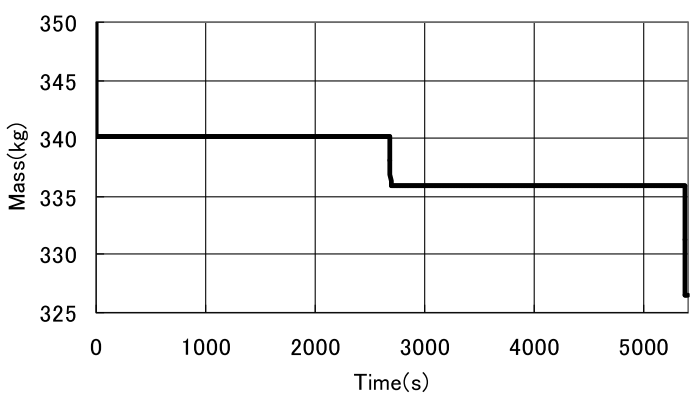

第 10 図 ホーマン遷移の質量履歴

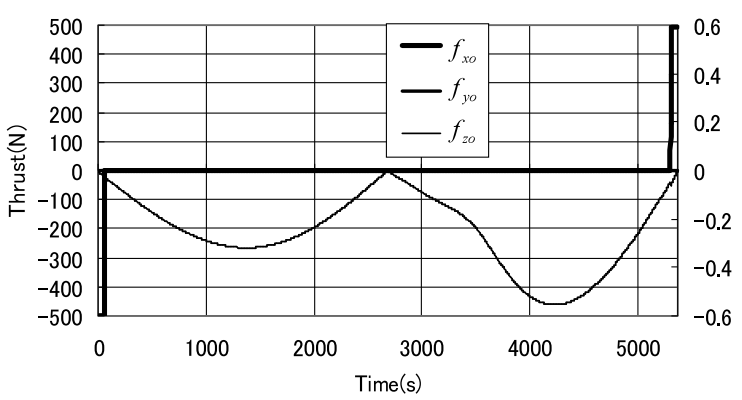

第 11 図 最適推力パターン (空気抵抗無視)

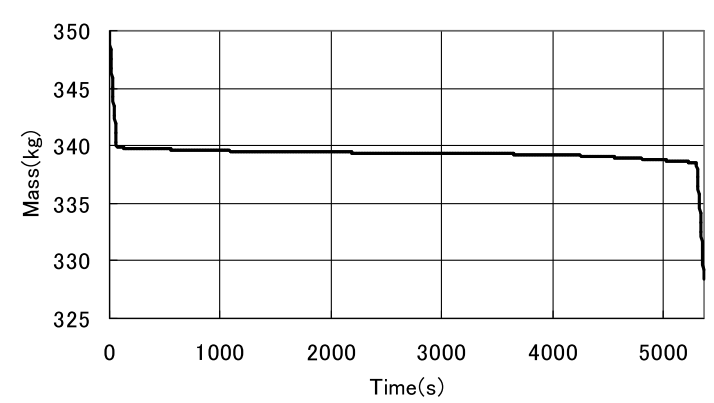

第 12 図 DAS の質量履歴 (空気抵抗無視)

変換と, 高度 $400 \mathrm{~km}$ と $100 \mathrm{~km}$ 間の高度変換を合わせて最 小の燃料消費で害現する最適制御の計算について説明する． この場合の評価関数は

$$
\begin{aligned}
\bar{J}= & \phi\left[\boldsymbol{x}\left(t_{\mathrm{f}}\right), t_{\mathrm{f}}\right] \\
= & {\left[m-\frac{1}{2} k_{r}\left(r-r_{\mathrm{f}}\right)^{2}-\frac{1}{2} k_{a}\left(a-a_{\mathrm{f}}\right)^{2}\right.} \\
& \left.\quad-\frac{1}{2} k_{p}\left(p-p_{\mathrm{f}}\right)^{2}-k_{i}\left(i-i_{\mathrm{f}}\right)^{2}\right]_{t_{\mathrm{f}}}
\end{aligned}
$$




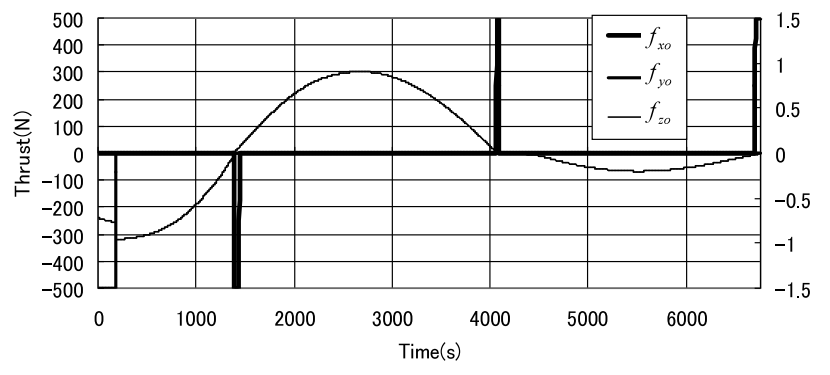

第13図 最適推力パターン

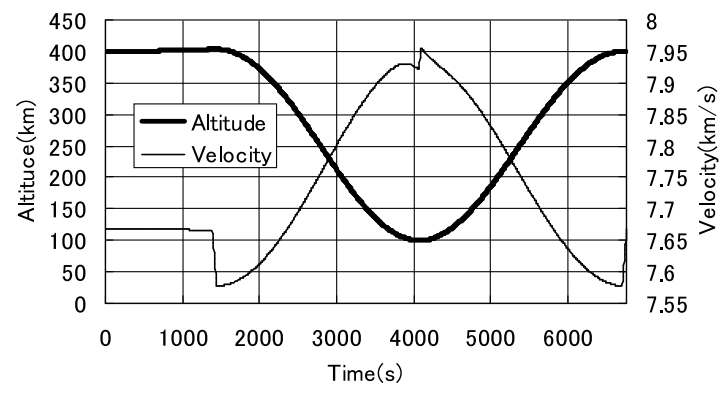

第14図 DAS の速度と軌道高度の履歴

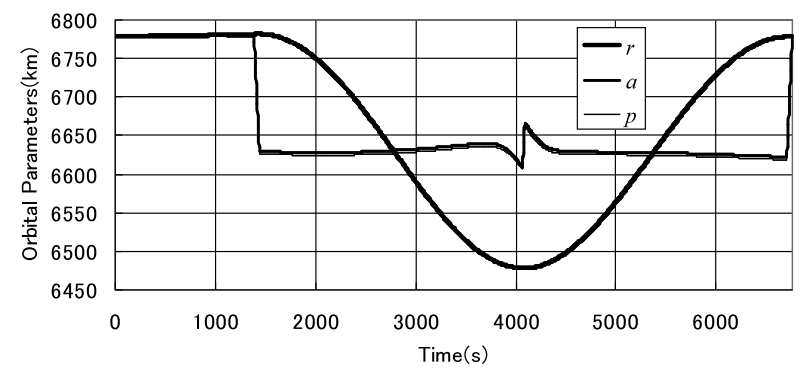

第 15 図 $r, a, p$ の履歴

となる . 計算の前半部分においては

$$
\left\{\begin{array}{l}
r_{\mathrm{f}}=6478.137 \mathrm{~km} \\
a_{\mathrm{f}}=6628.137 \mathrm{~km} \\
p_{\mathrm{f}}=6624.747 \mathrm{~km} \\
i_{\mathrm{f}}=2^{\circ}
\end{array}\right.
$$

とした . 停止時間は $T_{1}$ の半分とする場合，最適軌道の 近地点は単なる高度変換の近地点とあまり変わらないた め, ここで DAS が地球の中心に対して $3 / 4$ 周を回る時間 $t_{\mathrm{f}}=T_{0} / 4+T_{1} / 2=4075 \mathrm{~s}$ を停止時間とした . 計算の後半 部分においては

$$
\left\{\begin{array}{l}
r_{\mathrm{f}}=6778.137 \mathrm{~km} \\
a_{\mathrm{f}}=6778.137 \mathrm{~km} \\
p_{\mathrm{f}}=6778.137 \mathrm{~km} \\
i_{\mathrm{f}}=2^{\circ}
\end{array}\right.
$$

とし，停止時間を $t_{\mathrm{f}}=2685 \mathrm{~s}$ とした .

最適計算結果を第 13〜17 図に示す.最適推力パターン (第 13 図) から分かるように, $f_{y o}$ の値は長い時間負の最

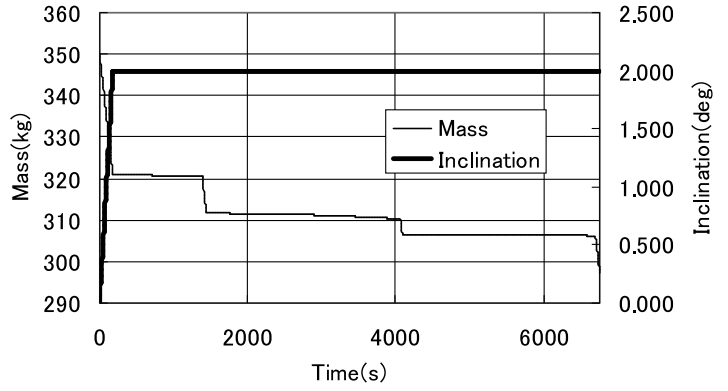

第 16 図 質量および軌道傾斜角の履歴

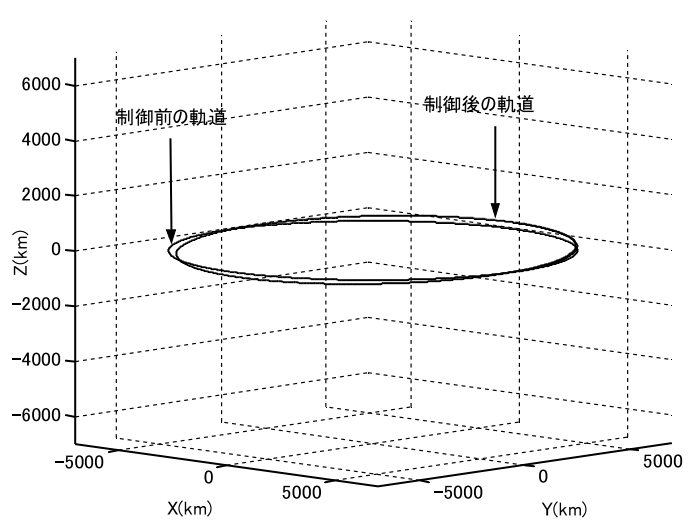

第 17 図 DAS の最適軌道

大値となっている．つまり， $Y_{o}$ 軸正方向のスラスタは長時 間噴射する必要がある . この噴射は軌道傾斜角の増加をも たらす． 衛星の高度および速度の履歴 (第 14 図) から分 かるように, 軌道面変換は軌道の高度および速度に対する 影響が少ない.軌道面変換は $r, a, p$ (第 15 图) に対す る影響も少ないことが分かる．質量およひ軌道傾斜角の履 歴 (第 16 図) から傾斜角は目標とする $2^{\circ}$ になっているこ とが分かる，一方，軌道面変換は衛星質量の急激減少を生 じる.この場合の燃料消費は $52.706 \mathrm{~kg}$ となり，衛星の初 期質量の $15.059 \%$ に達する. 即ち, 衛星の初期質量の半 分は燃料だとしても，同樣な制御を 4 回しか実行できない． また, 軌道面変換を行うと衛星は元の軌道面から離れてし まい，定常の観測機能が失われる.よって特に必要でない 限り軌道面変換を行わない方が良いと考えられる.

実用上は複数の DAS を用いてコンステレーションを形 成し，観測を実行する.DAS のコンステレーションは $6 \supset$ の極軌道面によって構成される (仮定) としよう.ある $t_{0}$ のときに某 A 地域で自然災害が発生したことが分かり，こ の地域の詳細な情報が必要な場合, $t_{0}$ の後 24 時間以内に $\mathrm{A}$ 点が描いた軌跡の線は必ずコンステレーションの軌道面 と 12 回交差する (地球が自転しているため). 兴の交差す る時間 $t_{i}(i=1,2, \cdots, 12)$ も交差点も明らかである. われわれはコンステレーションの中から適切な DAS を選 んで $t_{i}$ の前から降下させ,$t_{i}$ のときに交差点の上空近距離 へ到達させる制御を行えば，期待する観測精度が得られる． 


\section{5. 結}

論

本研究は DAS の降下および再上昇できる能力を利用し， 被災地を近距離で観測する方法を提案した。DAS の軌道変 換を燃料消費最小問題として定式化し，SAMA を用いて最 適解を求めた .

具体的には傾斜角 $97.049^{\circ}, 55^{\circ}, 0^{\circ}$ の軌道面において， 軌道高度 $400 \mathrm{~km}$ と $100 \mathrm{~km}$ 間の高度変換の最適計算を行っ た . 高度変換には $f_{x o}$ が主な役を果たすことが分かった . 近 地点付近で空気抵抗を克服するため, スラスタを噴射する 必要がある. 3 ケースの高度変換において傾斜角 $0^{\circ}$ の場合 が最も燃料消費が多い. 初期衛星質量の半分か燃料である と仮定すると, 高度变換が 9 回実行できる(傾斜角 $0^{\circ}$ の場 合, 9 回高度変換の燃料消費は初期衛星質量の $48.648 \%$ で ある) . 本計算と比較のためホーマン遷移と空気抵抗を無 視した場合の最適制御の計算を行った，最適制御の燃料消 費はホーマン遷移の燃料消費より $0.839 \mathrm{~kg}$ 多いこと，空気 抵抗を打ち消すため $2.751 \mathrm{~kg}$ の燃料が消費されることが分 かった .

高度变換 $\left(400 \mathrm{~km}\right.$ と $100 \mathrm{~km}$ の間) と軌道面変換 $\left(0^{\circ}\right.$ か ら $2^{\circ}$ まで) を合わせた軌道変換制御計算を行った，光の結 果僅か $2^{\circ}$ の軌道面を変えるため, スラスタを長時間噴射 しなければならず，多くの燃料を消費するため，特に必要 でない限り軌道変換を実行するべきではないことが分かっ た .また実用上の観測方法の一案を示した .
参 考 文 献

1) DAS Study Group: Preliminary Study on Dive and Ascent Satellite, DAS, Technical Report of National Aerospace Laboratory, TR-528, 1982.

2) Otsubo, K., Gaodai, T. and Nagasu, H.: Preliminary Trajectory Analysis for the Lowest-Flying Earth Satellite, DAS, Technical Report of National Aerospace Laboratory, TR-507, 1977.

3) Fu, T. and Imado, F.: A Basic Study on the Optimal Trajectory Control of a Dive and Ascent Satellite, Proceedings of SICE Annual Conference 2005, TA2-12-1, 2005, pp. 22552260.

4) 付 天爽, 今度史昭: Dive and Ascent 観測衛星の最適制御に 関する研究, 第 21 回誘導制御シンポジウム論文集 , 2004, pp. 71-78.

5）国立天文台 : 理科年表，丸善株式会社，東京，2006, pp. 559-560.

6) Imado, F.: A Study on the Spacecraft Nonlinear Optimal Orbit Control with Low-Thrusts, Proceedings of ICNPAA, 1998, pp. 287-296.

7) 冨田信之 : 宇宙システム入門, 東京大学出版会, 東京, 2000, pp. 48-50.

8) Takeuchi, S.: Theory of the Orbital Motion of an Artificial Earth Satellite, Technical Report of National Aerospace Laboratory, TR-807, 1984.

9) Takeuchi, S.: Atmospheric Drag Effects on the Motion of an Artificial Earth Satellite, Technical Report of National Aerospace Laboratory, TR-748, 1982.

10) Bryson Jr, A. E. and Denham, W. F.: A Steepest Ascent Method for Solving Optimum Programming Problems, J. Appl. Mech., 29 (1962), pp. 247-257. 